\title{
Development of a Rheumatology-specific Patient Concerns Inventory (PCl) and its use in the Rheumatology outpatient clinic setting
}

\author{
Ahmed AE, Lowe D, Kirton JA, O'Brien MR, Mediana A, Frankland H, Bruce $H$, \\ Kennedy T, Rogers SN and Moots RJ.
}

Abstract
Objectives

Successful management of rheumatic conditions involves increasing complexity of care. Delivering this in a holistic way is a growing challenge. The aim of this study was to develop a Patient Concerns Inventory (PCl) and assess it in the Rheumatology clinic setting.

\section{Methods}

This observational exploratory study occurred with two phases. Phase 1: the PCl was developed after systematic literature search, expert opinion and three patient focus group discussions. Phase 2: the $\mathrm{PCl}$ was piloted in a general Rheumatology clinic.

Results

Fifty-four patients were assessed in the pre-PCl group and 51 in the post-PCl group. Median (IQR) duration of consultation was 8 (5-14) minutes without $\mathrm{PCl}$ and 15 (10-20) minutes with $\mathrm{PCl}$. The pre$\mathrm{PCl}$ group raised 335 concerns from 50 patients, median (IQR) of 5 (3-10) per patient, rising post-PCI to 521 concerns, median (IQR) of 9 (5-16) from 51 patients, $p=0.002$. Additional concerns predominantly arising from 'Physical and functional well-being' and 'Social care and wellbeing' domains. Most patients rated their experience with their doctor in the consultation as excellent or outstanding across all 11 questions in the questionnaire, both before and after the introduction of the $\mathrm{PCl}$ to the clinic setting.

\section{Conclusion}

The $\mathrm{PCl}$ is a useful holistic needs assessment tool for Rheumatology clinics. Although its use may initially prolong the consultation slightly, patients can raise a significantly higher number of concerns that do not occur at the expense of patient satisfaction. This may help in identifying areas of 'unmet need', which previously went unnoticed.

Key messages

1) Patient concerns inventory ( $\mathrm{PCl})$ is a useful holistic needs assessment tool in Rheumatology clinics.

2) The $\mathrm{PCl}$ is able to highlight important areas of unmet needs in Rheumatology clinics.

3) The use of $\mathrm{PCl}$ enables patients to ask more questions which may lead to greater patient satisfaction. 


\section{Background}

Rheumatology services deal with a wide range of conditions that include inflammatory arthritis, osteoarthritis and connective tissue disorders, all of which may have profound detrimental effects on the quality of life. The care of Rheumatology diseases has improved considerably over the last few decades, with advent of biological agents ${ }^{1-7}$, establishment of registries and development of protocolized, target-driven disease management pathways. The net effect is to encourage early identification and manage disease as dynamically and actively as possible ${ }^{9-10}$. As a result of this paradigm shift and increasing financial pressures worldwide, patient encounters have become more pressured, with less time for interaction.

As rheumatic conditions tend to run a long term course, the need for a holistic approach is essential if the many different issues that patients may encounter ${ }^{11}, 12$, including pain, reduced function, loss of independence, fertility, appearance and psychological issues are to be adequately addressed. Some problems are potentially difficult, or embarrassing to talk about and therefore may be under-reported and under-recognised ${ }^{13,14}$ This problem can be compounded in a busy clinic, where the clinician, who may be a doctor, nurse, physiotherapist or occupational therapist, might not have the time to take an exhaustive history. It would therefore be advantageous to have a system in place that allows the patient and clinician to focus specifically on issues that are most relevant to the patient at that particular time.

Such a problem is not unique to Rheumatology. Rogers et al developed a 'Patient Concerns Inventory $(\mathrm{PCl})^{\prime}$ for use in patients with head and neck cancer ${ }^{15}$. The purpose of the $\mathrm{PCl}$ is to provide patients with a list of potential concerns, which they highlight shortly before their consultation, thereby assisting the clinician to focus on and address those issues that were most relevant to the individual patient. The ultimate aim is to improve efficiency of the consultation and patient satisfaction. Experience from the head and neck cancer $\mathrm{PCl}$ indicates that this is a feasible and effective tool for use in the outpatient setting ${ }^{16-25}$. A PCl was also piloted for the Neuro-Oncology setting ${ }^{26}$. The outcomes from that study showed that patient satisfaction was high and that the $\mathrm{PCl}$ was able to address many issues that were not covered by other general cancer needs assessment tools. A similar study of 21 patients was carried out in Breast Oncology ${ }^{27}$, where the $\mathrm{PCl}$ was able to identify 121 items of unmet need in patients with breast cancer.

There are many self-reported questionnaires already in use in Rheumatology such as RA-Qol (Rheumatoid Arthritis - Quality of life), BASDAI (Bath Ankylosing Spondylitis Disease Activity Index), BASFI (Bath Ankylosing Spondylitis Functional Index), AS-Qol (Ankylosing Spondylitis Quality of life), ASDAS (Ankylosing spondylitis Disease Activity Score), DAS-28 (Disease Activity Score for Rheumatoid arthritis), Visual Analogue Scale (VAS) and HAQ (Health Assessment Questionnaire) scores ${ }^{28-30}$. However, most of these are disease-specific and used to monitor disease activity or therapeutic response. Other scores are problem-specific, such as HAQ (physical activity) and VAS (pain). While there has been considerable effort invested in developing and measuring patient reported outcomes (PROMs) for rheumatic diseases, these have not been linked directly with patient concerns, which have rather been implied and not prospectively identified. We therefore set out to develop a tool that could allow a holistic needs assessment to be undertaken efficiently and effectively in the Rheumatology and which could subsequently inform the future design and interpretation of PROMs. 


\section{Methods}

In phase I, a Rheumatology specific PCl was developed, making use of literature, expert opinion from healthcare professionals and patient focus groups. In phase II, the $\mathrm{PCl}$ was piloted in a representative general Rheumatology outpatient clinic, analysing patient satisfaction and length of consultation.

\section{Phase I: Development of a Rheumatology Specific PCI}

A literature review was conducted to identify issues relevant to patients with musculoskeletal diseases. Searches used databases SCOPUS, PubMed and ISI Web of Knowledge. The initial search focused on finding papers that discussed unmet needs in Rheumatology and to ascertain whether any similar tools had been developed in the Rheumatology setting (Supplementary Data, appendix 1). A further search looked for papers that used any HRQoL (Health-Related Quality of life) measured within the Rheumatology setting. Papers were selected on their titles and compatibility with inclusion and exclusion criteria. Search terms were charted to subject headings. Abstracts of relevant papers were read and, when appropriate, full papers accessed. Subsequently, any relevant concerns within accessed HRQoL tools were extrapolated.

Second, 19 clinical specialists, comprising Rheumatology consultants, Rheumatology postgraduate trainees, Rheumatology specialist nurses, physiotherapist, occupational therapist, pharmacist, general medical trainees and an Orthopaedic surgeon were consulted about issues they considered most important to their patients. They were also given the task of further refining the list of $\mathrm{PCl}$ items from the literature review.

Third, 3 patient focus groups provided feedback regarding the $\mathrm{PCl}$, with patients from Rheumatology outpatient clinics at Aintree University Hospital. Patients that attended the clinic between February and April 2013 were given information about the study and asked if they would like to participate in the focus groups. All patients visiting the clinic during the recruitment period were invited to attend with no exclusions. 17 patients expressed an interest in being involved in the Focus groups. $16(n=4$, 5 and 7) patients attended focus groups, with one patient not attending. The age range was from 4670 years, with 7 male an 9 females. The focus groups were held in March and April 2013 in the hospital where the clinic was based. To encourage candour two non-clinical researchers (M.O and J.K., Edge Hill University), who were not associated with the Rheumatology clinic, facilitated the focus groups.

Participants had previously been given an information sheet about the study and were also given a copy of the $\mathrm{PCl}$ categories at the beginning of the focus group. The facilitators asked that participants to consider four questions when discussing each item to help aid the framing of their discussions:

(1) Is this something that might concern you or be important to you, either now or in the past or the future?

(2) Is this something that you might want to talk to your doctor or other healthcare professional about?

(3) Do you think that this item should be on the PCI?

(4) What do you think about the wording of this item? 
Patients were encouraged to discuss each item on the $\mathrm{PCl}$ list and the four questions were used as prompts if required. Patients were also asked to consider if they felt there were any items that should have been included on the $\mathrm{PCl}$ that were missed and to comment on the structure of the $\mathrm{PCl}$.

Written informed consent was obtained. The discussions were digitally recorded and the researchers made notes throughout, encouraging participants to clarify any ambiguous comments and guiding them through the items of the $\mathrm{PCl}$.

Focus group data were analysed using an adapted framework analysis approach (Ritchie \& Spencer, Furber) ${ }^{40,41}$, a robust and comprehensive method allowing researchers to systematically work through the data collected. This first involved researchers (M.O and J.K) immersing themselves in the data in order to develop an idea of the main discussion points around each area on the $\mathrm{PCl}$. Accordingly they listened to focus group recordings and they read and re-read verbatim transcriptions and the notes made at each focus group. Researchers used the draft $\mathrm{PCl}$ as a basis of the framework and tabulated overall responses to each point on the $\mathrm{PCl}$ for each focus group. As the objective of the focus group was very specific and conversation was kept to points on the $\mathrm{PCl}$, indexing and charting the data was a relatively easy process utilising the table produced in the framework stage of analysis. The data were synthesised by checking the framework chart against the original data sources to ensure proper recording of focus group opinion, which was summarised to give a clear overall opinion of each focus group and to incorporate any suggested comments.

Fourth, the same panel of clinical specialists were asked to split the $\mathrm{PCl}$ into four domains using the Delphi technique: Physical and functional well-being, Treatment related concerns, Social care and well-being, Psychological, emotional and spiritual well-being.

\section{Phase II: Pilot Study of the Rheumatology PCI}

The study was approved by the National Research Ethics Service (NRES) Northwest ethics board (REC reference 12/NW/0312). The $\mathrm{PCl}$ from Phase I was piloted in a consultant-led general Rheumatology clinic over a six month period between July and December 2013. All patients attending the clinic were eligible. Study awareness was raised using a poster on the clinic notice board. Before appointment, patients were sent an information sheet about this study. All patients were approached by research nurses before their clinic appointment and those who agreed to participate provided informed written consent. Demographic data was collected using electronic patient records (EDMS). The study design involved comparison of two different cohorts, one attending clinic prior to the introduction of the $\mathrm{PCl}$ (Pre-PCl cohort,) and the other attending clinic after the introduction of the $\mathrm{PCl}$ (Post- $\mathrm{PCl}$ cohort).

Pre-PCl patients attended for their clinic appointment as normal and were not asked to fill in the $\mathrm{PCl}$. A research nurse sat in clinic as an observer and ticked all the items on the $\mathrm{PCl}$ that were discussed without the patient having any knowledge of the PCl. For all patients the length of the consultation was recorded in minutes and after the consultation patients were asked to fill in a brief questionnaire about their satisfaction with the consultation. Data was also collected regarding the number and nature of referrals made and HAQ scores. Patient satisfaction was evaluated using an 11-item questionnaire devised by the Royal College of General Practitioners ${ }^{41}$. This questionnaire is used as a tool for assessing the performance of GP trainees, by providing a measure of the patient's opinion of the doctor's communication and empathy during a consultation. Patients were asked to rate 10 specific components, as well as overall satisfaction, using a seven-point Likert scale. Post-PCl, patients were asked to complete the $\mathrm{PCl}$ whilst in the waiting room before their clinic appointment and their 
responses on the $\mathrm{PCl}$ were passed to the consultant before the consultation began. All items selected by these patients were then addressed during the consultation.

The Mann-Whitney test was used to compare pre and post $\mathrm{PCl}$ groups in the number of $\mathrm{PCl}$ concerns, the Likert type questions on patient satisfaction, and also in respect of age, duration of illness, HAQ scores and duration of consultation. The mean score over all patient satisfaction questions was also compared. The Mann-Whitney test was similarly used to compare males and females. Fisher's exact test was used to compare pre and post $\mathrm{PCl}$ groups in regard to sex, onward referral and specific $\mathrm{PCl}$ concerns. Spearman's correlation coefficient $\left(r_{s}\right)$ was used to quantify the correlation between age, duration of illness, $\mathrm{HAQ}$ score, duration of consultation, number of $\mathrm{PCl}$ items and patient satisfaction.

\section{Results}

Phase I: Development of a Rheumatology Specific PCI

The first search (appendix 1 ) produced only eight relevant papers ${ }^{31-38}$, reflecting the present paucity of literature on unmet needs in Rheumatology. The second (appendix 1) produced many papers on the use of HRQoL measures within Rheumatology: most with only one HRQoL questionnaire and then used as secondary outcome measure. Kalyoncu et al ${ }^{39}$ discussed the use of HRQoL tools within 109 Rheumatology papers, published between 2005 and 2007, including frequency of use. We attempted to access all the HRQoL tools highlighted within this review.

The clinical specialist assessment of potential patient concerns from the literature search led to the generation of a list of 38 potential concerns, which after discussions in patient focus groups led to a refined $\mathrm{PCl}$ comprising 39 items, which were distributed into 4 cognate domains, which corresponded to those for other PCls.

Phase II: Pilot Study of the Rheumatology PCI

Full details listing broad demographics and diagnoses for 54 patients in the pre- $\mathrm{PCl}$ group and 51 patients in the post- $\mathrm{PCl}$ group are shown in Table 1 . Nineteen per cent (10/54) of the pre- $\mathrm{PCl}$ and $24 \%$ $(12 / 51)$ of the post PCl group had newly diagnosed disease. Twenty four per cent $(13 / 54)$ of the PCl group had their diagnosis established more than 10 years previously compared to $53 \%(27 / 51)$ of the post- $\mathrm{PCl}$ group. Pre-PCl patients had lower $\mathrm{HAQ}$ scores than those in the post- $\mathrm{PCl}$ group (Table 1 ). Median (IQR) duration of consultation without PCl was 8 (5-14) minutes and with $\mathrm{PCl}$ was 15 (10-20) minutes. Two patients (4\%) in the pre-PCI group required referrals to other specialties whereas no post- $\mathrm{PCl}$ patient required onward referral, $p=0.50$. Both groups lived with a variety of rheumatic conditions (Table 1).

A total of 335 concerns were raised in the pre-PCl group from 50 patients, median (IQR) of 5 (3-10) per patient, rising to 521 concerns, median (IQR) of $9(5-16)$ from 51 post-PCl patients, $p=0.002$. This rise was noted predominantly from within the 'Physical and functional well-being' and 'Social care and wellbeing' domains (Table 2). In the 'Physical and functional well-being' domain the pre-PCl median (IQR) of $2(0-4)$ and total 140 concerns rose to a post-PCI median (IQR) of 5 (2-8) and total 247 concerns, $\mathrm{p}<0.001$. Particular concerns more frequently discussed after the $\mathrm{PCl}$ was introduced related to poor mobility, poor hand function, poor sleep, lack of energy and poor range of joint movement. For the 'Social care and wellbeing' domain the pre-PCI median (IQR) of $0(0-1)$ and total 16 concerns rose to a post-PCl median (IQR) of $1(0-2)$ and total 71 concerns, $p<0.001$. Particular 
concerns more often discussed with the $\mathrm{PCl}$ were concerned with it being hard to exercise, things to avoid, aids and adaptation / occupational therapy and difficulty with / needing assistance with activities of daily living. For the 'Treatment-related concerns' domain there was little difference between pre and post PCl groups overall, both with a median (IQR) of 2 (1-4) concerns and little difference in total number (123 and 128), $p=0.80$. There was also no significant difference, $p=0.48$, in regard to the 'Psychological, emotional and spiritual well-being' domain, both with a median (IQR) of $1(0-2)$ concerns and total number 56 and 75 . However it was noted that whilst after the introduction of the $\mathrm{PCl}$ there was more discussion regarding sexual relationships, difficulties with activities of interest and enjoyment of life/loss of social activities these were counterbalanced by less discussion about understanding of the patient's illness.

In the pre- $\mathrm{PCl}$ group only pain was discussed with more than half of patients (Table 2, Figure 1). Infrequently discussed concerns, i.e. with under $5 \%$ of patients, were 'surgery', 'need assistance with activities of daily living', 'lack of medical, nursing and/or social support', 'things to avoid', 'aids and adaptation/ occupational therapy', 'finance', 'hard to exercise', 'problems with driving', 'illegal drugs', 'enjoyment of life/ loss of social activities', 'access to support group', 'sexual relationship', 'difficulties with activities of interest such as gardening and other activities'. However, in the post-PCl group (Table 2, Figures 1\&2), 'pain', 'joint stiffness', 'swollen and tender joints', 'poor mobility', 'poor sleep' and 'lack of energy' were discussed with more than half of patients whilst only 'illegal drugs' concern was discussed with fewer than $5 \%$ of patients. The proportion of patients reporting each concern in the post- $\mathrm{PCl}$ group is detailed in Figure 1.

The vast majority of patients rated their experience with their doctor in the consultation as being excellent or outstanding across all 11 questions in the questionnaire, both before and after the introduction of the $\mathrm{PCl}$ to the clinic setting (Table 3). There were nine consultations pre- $\mathrm{PCl}$ for which one or more of the responses to the 11 questions were less than 'very good' as compared to seven consultations post- $\mathrm{PCl}$. Mean scores were slightly higher in the post- $\mathrm{PCl}$ group though, for none of the questions was there a statistically significant difference between the two sets (pre vs. post) of responses. The overall mean score (the mean of the responses across all 11 questions) was also slightly higher, median (IQR) of 6.18 (5.45-6.18) pre-PCl and 6.41 (5.68-7.00) post $\mathrm{PCl}, \mathrm{p}=0.65$.

Other analyses were performed to investigate the level of association between the baseline variables of age, gender, $\mathrm{HAQ}$ score and duration of illness with length of consultation, patient satisfaction and the number of $\mathrm{PCl}$ items. Both pre and post $\mathrm{PCl}$ groups were combined for these analyses. No statistical association was seen at $p<0.01$ between any of these baseline variables and duration of consultation, nor between age or duration of illness with either the number of $\mathrm{PCl}$ items or with patient satisfaction. There was however significant correlation between HAQ score and the number of $\mathrm{PCl}$ items with higher $\mathrm{HAQ}$ scores tending to go with a greater number of $\mathrm{PCl}$ concerns in the 'Physical and functional well-being' domain $\left(r_{s}=0.34, p=0.004\right)$, the 'Treatment related concerns' domain $\left(r_{s}=0.27, p=0.02\right)$ and total number $\left(r_{s}=0.34, p=0.003\right)$ but not with the other two domains $\left(r_{s}=0.03\right.$ and $r_{s}=0.00$ respectively). There were also negative correlations of borderline significance with the patient satisfaction questions ranging from $r_{s}=-0.28$ to $r_{s}=-0.14$, median $r_{s}=-0.25$, and with the overall mean patient satisfaction score $r_{s}=-0.25, p=0.05$, indicating the tendency for higher HAQ scores to go with lower (worse) satisfaction scores. These correlations involving HAQ scores were generally 'weak' but as HAQ score seems to be a potential confounder to the comparisons made between pre and post $\mathrm{PCl}$ groups the results were stratified and are shown in Table 4. The tendency remains towards having more $\mathrm{PCl}$ concerns post $\mathrm{PCl}$ for $\mathrm{HAQ}$ scores between 0.50 and 0.99 , for scores of 1.00 and above and for when scores were not known, and there were too few scores below 0.50 in the post- $\mathrm{PCl}$ group to pass comment. There was also a consistent trend towards greater satisfaction post$\mathrm{PCl}$ for $\mathrm{HAQ}$ scores $0.50-0.99$ and of 1.00 and above. 
Duration of consultation was also associated with the number of $\mathrm{PCl}$ items in three of the four domains and overall, $r_{s}=0.36$ overall $p<0.001$. There was a median of 5 concerns for consultations under 10 minutes, 7 when 11-19 minutes and 10 when longer than 20 minutes. Amongst the baseline variables gender was associated with $\mathrm{HAQ}$ scores, $\mathrm{p}=0.001$ with females having lower HAQ scores (median 0.38 vs. 0.88). Duration of illness was also associated with HAQ score, $r_{s}=0.32, p=0.006$. Median HAQ score was 0.44 for duration $0-1$ years, 0.75 for 2-9 years and 0.88 for 10 or more years. Duration of illness was also associated with age, $r_{s}=0.44, p<0.001$.

\section{Discussion:}

We have developed a novel instrument with potential utility across a whole range of rheumatological conditions. It is able to facilitate the identification of concerns that patients may have, but perhaps not be able to otherwise raise with their clinician. Our data demonstrated that, despite the overall longer duration of illness and higher mean HAQ scores, the patient satisfaction in the post PCl group remained high. This may, in part at least, be due to the fact that patients in the post $\mathrm{PCl}$ group asked significantly more questions and discussed a greater number of concerns compared to the pre-PCl group (see table 2). It has previously been demonstrated that patient satisfaction increases significantly when interventions are designed to encourage patients to ask questions ${ }^{43}$. The fact that the baseline patient satisfaction in this particular clinic was so high unfortunately meant that it was not practical to detect significant changes in satisfaction after implementation of the $\mathrm{PCl}$. We are now in the process of evaluating it across other clinics.

Although the mean duration of consultation increased slightly for the post-PCl group, it is important to remember that the $\mathrm{PCl}$ was able to identify a significantly higher number of items of unmet need, mainly from the 'Physical and functional well-being' and the 'Social care and well-being' domains (table 2). This was due to the fact that $\mathrm{PCl}$ provided patients the opportunities to discuss potential problems such as sexual relationships, difficulties with activities of interest and enjoyment of life and loss of social activities, amongst others. These were clearly important concerns for many patients that they had hitherto been unable to discuss, despite access to primary care doctors, Rheumatology nurse advice-lines and Rheumatology clinics. Part of the problem might lie in the patients' perceived acceptability of asking certain questions. However, this would appear to become easier when potential specific concerns are presented on a checklist and is more reassuring for the patient that it is appropriate to ask such questions. Thus, $\mathrm{PCl}$ provides an opportunity to improve doctor-patient communication. Additionally, the $\mathrm{PCl}$ also serves as a visual aid for both doctors and patients, reminding them about the different aspects of care thus becoming a novel and powerful tool for holistic needs assessment.

There are a number of potential limitations to this study. Whilst we took great pains to devise a list of concerns from literature search, expert opinion and also focus groups, it is possible that important potential concerns were missed. This can be addressed as the tool is used more widely. We also evaluated the instrument in only one clinic - however, we believe that the number of patients studied was sufficient to detect the initial changes that we set out to evaluate and determine if it was an appropriate tool to roll our further. We felt that there were also advantages of consistency if initially studies used only one clinician. Finally, the difference in disease duration between the two groups might have potentially led to a difference in needs. Indeed, understanding possible changes of needs with time is a focus for future work with this tool.

We believe that the $\mathrm{PCl}$ is a useful holistic needs assessment tool in Rheumatology clinics, where it can highlight important areas of unmet need. Our study demonstrates that, with the use of $\mathrm{PCl}$, 
patients are able to discuss a significantly higher number of concerns that would otherwise go unrecognised when the traditional consultation style is used. While Rheumatologists may not be able to deal with all the concerns directly or even during the same appointment, this should prompt appropriate referrals with suitable follow-up to ensure the concerns are adequately addressed.

Disclosure statement: The authors declare no conflict of interest.

Funding: None

\section{References}

1) Beukelman T. Treatment advances in systemic juvenile idiopathic arthritis. F1000Prime Rep. 2014 Apr 1; 6:21.

2) Smolen JS, Landewé R, Breedveld FC, Buch $M$, Burmester G, Dougados $M$, Emery $P$, GaujouxViala C, Gossec L, Nam J, Ramiro S, Winthrop K, de Wit M, Aletaha D, Betteridge N, Bijlsma JW, Boers M, Buttgereit F, Combe B, Cutolo M, Damjanov N, Hazes JM, Kouloumas M, Kvien TK, Mariette X, Pavelka K, van Riel PL, Rubbert-Roth A, Scholte-Voshaar M, Scott DL, Sokka-Isler $T$, Wong JB, van der Heijde D. EULAR recommendations for the management of rheumatoid arthritis with synthetic and biological disease-modifying antirheumatic drugs: 2013 update. Ann Rheum Dis. 2014 Mar; 73(3):492-509.

3) Emery P, Sebba A, Huizinga TW. Biologic and oral disease-modifying antirheumatic drug monotherapy in rheumatoid arthritis. Ann Rheum Dis. 2013 Dec; 72(12):1897-904.

4) Pateinakis P, Pyrpasopoulou A. Targeting the B-cell pathway in lupus nephritis: current evidence and future perspectives. ScientificWorldJournal. 2013 Sep 26; 2013:745239.

5) Jordan N, Lutalo PM, D'Cruz DP. Novel therapeutic agents in clinical development for systemic lupus erythematosus. BMC Med. 2013 May 3; 11:120.

6) Barr A, Keat A. Spondyloarthritides: evolving therapies. Arthritis Res Ther. 2010; 12(6):221.

7) Mease P. Update on treatment of psoriatic arthritis. Bull NYU Hosp Jt Dis. 2012; 70(3):167-71.

8) Bloom S. Registries in chronic disease: coming your way soon? Registries-problems, solutions and the future. Rheumatology 2011; 50:4_5.

9) Schneider M, Krüger K. Rheumatoid arthritis--early diagnosis and disease management. Dtsch Arztebl Int. 2013 Jul; 110(27-28):477-84

10) Cardiel MH. Treat to target strategy in rheumatoid arthritis: real benefits. Reumatol Clin. 2013 Mar-Apr; 9(2):101-5.

11) Kjeken I, Dagfinrud H, Mowinckel P, Uhlig T, Kvien TK, Finset A. Rheumatology care: involvement in medical decisions, received information, satisfaction with care, and unmet 
health care needs in patients with rheumatoid arthritis and ankylosing spondylitis. Arthritis and Rheumatism 2006, 55(3): 394-401.

12) Gilworth G, Haigh R, Tennant A, Chamberlain MA, Harvey AR. Do rheumatologists recognise their patients' work-related problems? Rheumatology 2001, 40(11): 1206-10.

13) Hill J, Bird H, Thorpe R. Effects of rheumatoid arthritis on sexual activity and relationships. Rheumatology 2003, 42(2): 280-6.

14) Clowse MEB, Chakravarty E, Costenbader KH, Chambers C and Michaud K. 2012 Effects of Infertility, Pregnancy Loss, and Patient Concerns on Family Size of Women With Rheumatoid Arthritis and Systemic Lupus Erythematosus. Arthritis Care and Research 64(5) 668-674].

15) Rogers SN, El-Sheikha J, Lowe D. The development of a Patient Concerns Inventory (PCI) to help reveal patients concerns in the head and neck clinic. Oral Oncology 2009, 45: 555-561.

16) Rogers SN, Cleator AJ, Lowe D, Ghazali N. Identifying pain-related concerns in routine followup clinics following oral and oropharyngeal cancer. World J Clin Oncol 2012 August 10; 3(8): 116-125.

17) Ghazali N, Lowe $D$, Rogers SN. Enhanced patient reported outcome measurement suitable for head and neck cancer follow-up clinics. Head \& Neck Oncology 2012, 4:32.

18) Ghazali N, Kanatas A, Scott B, Lowe D, Zuydam A, Rogers SN. Use of the Patient Concerns Inventory to identify speech and swallowing concerns following treatment for oral and oropharyngeal cancer. J Laryngol Otol. 2012 Aug; 126(8):800-8.

19) Ghazali N, Kanatas A, Langley DJ, Scott B, Lowe D, Rogers SN. Treatment referral before and after the introduction of the Liverpool Patients Concerns Inventory ( $\mathrm{PCl})$ into routine head and neck oncology outpatient clinics. Support Care Cancer. 2011 Nov; 19(11):1879-86.

20) Scott B, Ghazali N, Lowe D, Bekiroglu F, Rogers SN. The Patients Concerns Inventory in head and neck cancer: comparison between self-completed paper and touch screen versions in the clinic setting. Eur J Oncol Nurs. 2013 Dec; 17(6):863-9.

21) Kanatas A, Ghazali N, Lowe D, Rogers SN. The identification of mood and anxiety concerns using the patients concerns inventory following head and neck cancer. Int J Oral Maxillofac Surg. 2012 Apr; 41(4):429-36.

22) Rogers $S N$, Scott $B$, Lowe $D$, Ozakinci G, Humphris GM. Fear of recurrence following head and neck cancer in the outpatient clinic. Eur Arch Otorhinolaryngol. 2010 Dec; 267(12):19439.

23) Kanatas A, Ghazali N, Lowe D, Udberg M, Heseltine J, O'Mahony E, Rogers SN. Issues patients would like to discuss at their review consultation: variation by early and late stage oral, oropharyngeal and laryngeal subsites. Eur Arch Otorhinolaryngol. 2013 Mar; 270(3):1067-74. 
24) Ghazali N, Roe B, Lowe D, Rogers SN. Uncovering patients' concerns in routine head and neck oncology follow up clinics: an exploratory study. Br J Oral Maxillofac Surg. 2013 Jun; 51(4):294-300.

25) Hatta JM, Doss JG, Rogers SN. The feasibility of using Patients Concerns Inventory (PCI) in managing Malaysian oral cancer patients. Int J Oral Maxillofac Surg. 2013 Sep 24. pii: S09015027(13)01073-4.

26) Rooney AG, Netten A, McNamara S, Erridge S, Peoples S, Whittle I, Hacking B, Grant R. Assessment of a brain-tumour-specific Patient Concerns Inventory in the neuro-oncology clinic. Support Care Cancer. 2013 Nov 29. [Epub ahead of print].

27) Jiwa M, Ping-Delfos WC, Briffa K, Sherriff J, Merriman G, Nockolds J, Jardine L, Musiello T, Longman G. Developing a Self-Administered Questionnaire as a Guide to Consultations with Women Treated for Breast Cancer. International Journal of Family Medicine Volume 2011, Article ID 390692, 5 pages. doi:10.1155/2011/390692.

28) Linde L, Sørensen J, Ostergaard M, Hørslev-Petersen K, Hetland ML. Health-related quality of life: validity, reliability, and responsiveness of SF-36, 15D, EQ-5D [corrected] RAQoL, and HAQ in patients with rheumatoid arthritis. J Rheumatol. 2008 Aug; 35(8):1528-37.

29) Hernández Alava M1, Wailoo A, Wolfe F, Michaud K. The relationship between EQ-5D, HAQ and pain in patients with rheumatoid arthritis. Rheumatology 2013; 52:944_950.

30) Romero-Sánchez C, Londoño J, DE Avila J, Valle-Oñate R. Biomarkers for spondyloarthropathies. State of the art. Rev Med Chil. 2010 Sep; 138(9):1179-85.

31) Cunha-Miranda L, Costa L, Ribeiro JS. Near study: Needs and expectations in rheumatoid arthritis - Do we know our patients needs? Acta Rheumatol Port. 2010; 35(3): 314-23.

32) Kjeken I, Dagfinrud H, Mowinckel P, Uhlig T, Kvein TK, Finset A. Rheumatology care: Involvement in medical decisions, received information, satisfaction with care, and unmet health care needs in patients with rheumatoid arthritis and ankylosing spondylitis. Arthritis Rheum 2006; 55(3): 394-401.

33) Rome K, Chapman J, Williams AE, Gow P, Dalbeth N. Podiatry services for patients with arthritis: an unmet need. N Z Med J. 2010; 123(1310): 91-7.

34) Martin LJ, Griffith SM. High disease activity scores predict the need for additional health services in patients over 60 with rheumatoid arthritis. Musculoskeletal Care 2006; 4(1): 1-11.

35) Wikstrom I, Isacsson A, Jacobsson LTH. Leisure activities and rheumatoid arthritis: change after disease onset and associated factors. Br J Occup Ther 2001; 64: 87-92.

36) Fitzcharles MA, DaCosta D, Ware MA, Shir Y. Patient barriers to pain management may contribute to poor pain control in rheumatoid arthritis. J Pain 2009; 10(3): 300-5. 
37) Marshall NJ, Wilson G, Lapworth K, Kay LJ. Patients' perceptions of treatment with anti-TNF therapy for rheumatoid arthritis: a qualitative study. Rheumatology 2004; 43(8): 1034-8.

38) Monaghan SM, Sharpe L, Denton F, Levy J, Schrieber L, Sensky T. Relationship between appearance and psychological distress in rheumatic diseases. Arthritis Rheum 2007; 57(2): 303-9.

39) Kalyoncu U, Dougados M, Daures JP, Gossec L. Reporting of patient-reported outcomes in recent trials in rheumatoid arthritis: a systematic literature review. Ann Rheum Dis. 2009; 68(2): 183-90.

40) Ritchie, J \& Spencer, L. (1994) Qualitative Data Analysis for Applied Policy Research. Cited in: Bryman, A \& Burgess, RG. (1994) Analysing Qualitative Data. Routledge. London p 173-94.

41) Furber, C (2010) Framework analysis: A Method for Analysing Qualitative Data. African Journal of Midwifery and Women's Health. Apr-June. Vol 4. No. 2.

42) Royal College of General Practitioners. The Patient Satisfaction Questionnaire. http://www.rcgp-curriculum.org.uk/mrcgp/wpba/psq.aspx.

43) Kinnersley P1, Edwards A, Hood K, Cadbury N, Ryan R, Prout H, Owen D, Macbeth F, Butow $P$, Butler $C$. Interventions before consultations for helping patients address their information needs. Cochrane Database of Systematic Reviews (2007), Issue 3. Art. No: CD004565. 
Table 1. Age, sex, duration of illness, diagnosis, duration of consultation, HAQ scores and onward referral for the two groups of patients before and after the introduction of the $\mathrm{PCl}$.

\begin{tabular}{|c|c|c|}
\hline & Pre-PCI group $(n=54)$ & Post- $\mathrm{PCl}$ group $(\mathrm{n}=51)$ \\
\hline Sex, male: female, $\mathrm{n}$ & $17: 37$ & $11: 40$ \\
\hline Age, mean (SD), years & $53(16)$ & $56(16)$ \\
\hline${ }^{*}$ Duration of illness, median (IQR), years & $3(1-9)$ & $10(2-13)$ \\
\hline \multicolumn{3}{|l|}{ Diagnosis (n) } \\
\hline Rheumatoid arthritis & 19 & 22 \\
\hline Not established & 14 & 6 \\
\hline Systemic sclerosis & 1 & 0 \\
\hline Polymyalgia rheumatica & 1 & 1 \\
\hline Stills disease & 1 & 1 \\
\hline Gout & 2 & 0 \\
\hline Unspecified inflammatory arthritis & 1 & 1 \\
\hline Ankylosing spondylitis & 1 & 0 \\
\hline Granulomatosis with polyangiitis & 2 & 0 \\
\hline Fibrodysplasia ossificares progressiva & 1 & 0 \\
\hline Sjogrens syndrome & 2 & 2 \\
\hline Behcet's syndrome & 1 & 0 \\
\hline Osteoarthritis & 1 & 2 \\
\hline Palindromic rheumatism & 1 & 0 \\
\hline Psoriatic arthritis & 1 & 5 \\
\hline Fibromyalgia & 1 & 0 \\
\hline Pauci articular arthritis & 1 & 0 \\
\hline *Systemic lupus erythematosus (SLE) & 1 & 8 \\
\hline Reactive arthritis & 1 & 0 \\
\hline Myositis & 1 & 0 \\
\hline Seronegative spondyloarthritis & 0 & 1 \\
\hline Juvenile idiopathic arthritis (JIA) & 0 & 1 \\
\hline Inflammatory monoarthritis & 0 & 1 \\
\hline ***Duration of consultation, median (IQR), minutes & $8(5-14), n=51$ & $15(10-20), n=50$ \\
\hline HAQ scores, median (IQR), n & $0.44(0.13-0.97), n=40$ & $0.88(0.56-1.00), \mathrm{n}=33$ \\
\hline Referrals to other specialties, $\mathrm{n}$ & 2 & 0 \\
\hline
\end{tabular}

${ }^{*} 0.01 \leq p<0.05,{ }^{* *} 0.001 \leq p<0.01,{ }^{* * *} p<0.001$ 
Table 2. Concerns discussed by patients, before and after the introduction of the PCI to the clinic setting

\begin{tabular}{|c|c|c|c|c|}
\hline Domain & Specific concern & $\begin{array}{c}\text { Highlighted } \\
\text { Pre-PCl } \\
\left(n=50^{*}\right) \\
\end{array}$ & $\begin{array}{l}\text { Highlighted } \\
\text { Post PCl } \\
\text { (n=51) }\end{array}$ & $P$ value** \\
\hline \multirow{10}{*}{$\begin{array}{l}\text { D1: Physical and } \\
\text { functional well- } \\
\text { being }\end{array}$} & Pain & 36 & 34 & 0.67 \\
\hline & Joint stiffness & 24 & 34 & 0.07 \\
\hline & Swollen and tender joints & 25 & 28 & 0.69 \\
\hline & Joint deformity & 10 & 14 & 0.48 \\
\hline & Poor range of joint movement & 11 & 22 & 0.03 \\
\hline & Poor mobility & 8 & 26 & $<0.001$ \\
\hline & Poor hand function & 9 & 24 & 0.003 \\
\hline & Poor sleep & 8 & 33 & $<0.001$ \\
\hline & Lack of energy & 9 & 32 & $<0.001$ \\
\hline & Total concerns & 140 & 247 & \\
\hline \multirow{11}{*}{$\begin{array}{l}\text { D2: Treatment } \\
\text { related concerns }\end{array}$} & Disease progression & 18 & 21 & 0.68 \\
\hline & Treatment side effects & 24 & 15 & 0.07 \\
\hline & Weight changes with treatment & 4 & 11 & 0.09 \\
\hline & Drug interactions & 9 & 14 & 0.34 \\
\hline & Treatment ineffective & 10 & 9 & 0.80 \\
\hline & Surgery & 2 & 6 & 0.27 \\
\hline & Continuity of care (seeing different doctors each time) & 9 & 8 & 0.80 \\
\hline & Blood tests and other investigations you wanted to discuss & 22 & 21 & 0.84 \\
\hline & Information on what to do in a flare-up situation & 16 & 16 & $>0.99$ \\
\hline & Access to doctors/ nurses & 9 & 7 & 0.60 \\
\hline & Total concerns & 123 & 128 & \\
\hline \multirow{11}{*}{$\begin{array}{l}\text { D3: Social care } \\
\text { and well-being }\end{array}$} & Need assistance with activities of daily living & 1 & 8 & 0.03 \\
\hline & $\begin{array}{l}\text { Difficulty with activities of daily living such as caring for self, dressing } \\
\text { and house work }\end{array}$ & 6 & 15 & 0.05 \\
\hline & Lack of medical, nursing and/or social support & 0 & 3 & 0.24 \\
\hline & What to avoid & 0 & 6 & 0.03 \\
\hline & Aids and adaptation/ occupational therapy & 2 & 10 & 0.03 \\
\hline & Finance & 0 & 5 & 0.06 \\
\hline & Hard to exercise & 0 & 16 & $<0.001$ \\
\hline & Problems with driving & 0 & 3 & 0.24 \\
\hline & Work and employment & 7 & 4 & 0.36 \\
\hline & Illegal drugs & 0 & 1 & $>0.99$ \\
\hline & Total concerns & 16 & 71 & \\
\hline \multirow{10}{*}{$\begin{array}{l}\text { D4: Psychological, } \\
\text { emotional and } \\
\text { spiritual well- } \\
\text { being }\end{array}$} & Anxiety/ depression & 6 & 13 & 0.13 \\
\hline & Enjoyment of life/ loss of social activities & 2 & 12 & 0.008 \\
\hline & Worry of the future & 3 & 9 & 0.12 \\
\hline & Understanding my illness & 24 & 9 & 0.001 \\
\hline & Access to support group & 1 & 3 & 0.62 \\
\hline & Sexual relationship & 0 & 5 & 0.06 \\
\hline & Self-esteem & 9 & 9 & $>0.99$ \\
\hline & $\begin{array}{l}\text { Difficulties with activities of interest such as gardening and other } \\
\text { activities }\end{array}$ & 1 & 8 & 0.03 \\
\hline & Are you concerned about the accuracy of your diagnosis & 10 & 7 & 0.44 \\
\hline & Total concerns & 56 & 75 & \\
\hline
\end{tabular}

* Observational data were not available for 4 of the 54 pre-PCI patients

**Fishers exact test 
Table 3. Patient satisfaction *Mann-Whitney test

\begin{tabular}{|c|c|c|c|c|c|c|c|c|c|c|c|}
\hline $\begin{array}{l}\text { In your consultation today how good } \\
\text { was your doctor at: }\end{array}$ & & $\begin{array}{l}\text { Poor to } \\
\text { Fair (1) }\end{array}$ & Fair (2) & $\begin{array}{l}\text { Fair to } \\
\text { Good } \\
(3)\end{array}$ & $\begin{array}{l}\text { Good } \\
(4)\end{array}$ & $\begin{array}{l}\text { Very } \\
\text { Good } \\
(5)\end{array}$ & $\begin{array}{l}\text { Excelle } \\
\text { nt (6) }\end{array}$ & $\begin{array}{l}\text { Outsta } \\
\text { nding } \\
(7)\end{array}$ & $\begin{array}{l}\text { Total } \\
\text { cases }\end{array}$ & $\begin{array}{c}P \\
\text { Value* }\end{array}$ & $\begin{array}{l}\text { Mean } \\
\text { score }\end{array}$ \\
\hline \multirow{2}{*}{$\begin{array}{l}\text { Q1: Making you feel at ease? (being friendly and } \\
\text { warm towards you, treating you with respect; not } \\
\text { cold or abrupt) }\end{array}$} & Pre-PCI & 1 & 1 & - & 3 & 5 & 16 & 24 & 50 & \multirow{2}{*}{0.33} & 6.08 \\
\hline & Post-PCl & - & - & - & - & 4 & 20 & 26 & 50 & & 6.44 \\
\hline \multirow{2}{*}{$\begin{array}{l}\text { Q2: Letting you tell "your" story? (giving you time to } \\
\text { fully describe your illness in your own words; not } \\
\text { interrupting or diverting you) }\end{array}$} & Pre-PCl & 1 & 1 & - & 3 & 9 & 14 & 23 & 51 & \multirow{2}{*}{0.93} & 5.98 \\
\hline & Post-PCl & - & - & - & 3 & 7 & 20 & 20 & 50 & & 6.14 \\
\hline \multirow{2}{*}{$\begin{array}{l}\text { Q3: Really listening? (paying close attention to what } \\
\text { you were saying; not looking at the notes or the } \\
\text { computer as you were talking) }\end{array}$} & Pre-PCI & 1 & 2 & - & 3 & 9 & 12 & 24 & 51 & \multirow{2}{*}{0.60} & 5.92 \\
\hline & Post-PCl & - & - & - & 2 & 8 & 17 & 23 & 50 & & 6.22 \\
\hline \multirow{2}{*}{$\begin{array}{l}\text { Q4: Being interested in you as a whole person? } \\
\text { (asking/knowing relevant details about your life, } \\
\text { your situation; not treating you as "just a number") }\end{array}$} & Pre-PCl & 2 & 1 & - & 5 & 6 & 13 & 22 & 49 & \multirow{2}{*}{0.31} & 5.84 \\
\hline & Post-PCl & - & - & - & 3 & 6 & 16 & 25 & 50 & & 6.26 \\
\hline \multirow{2}{*}{$\begin{array}{l}\text { Q5: Fully understanding your concerns? } \\
\text { (communicating that he/she had accurately } \\
\text { understood your concerns; not overlooking or } \\
\text { dismissing anything) }\end{array}$} & Pre-PCl & 1 & 2 & - & - & 11 & 15 & 22 & 51 & \multirow{2}{*}{0.60} & 5.96 \\
\hline & Post-PCI & - & - & - & 4 & 9 & 12 & 25 & 50 & & 6.16 \\
\hline \multirow{2}{*}{$\begin{array}{l}\text { Q6: Showing care and compassion? (seeming } \\
\text { genuinely concerned, connecting with you on a } \\
\text { human level; not being indifferent or "detached") }\end{array}$} & Pre-PCI & 2 & - & - & 4 & 7 & 16 & 22 & 51 & \multirow{2}{*}{0.44} & 5.94 \\
\hline & Post-PCl & - & - & - & 1 & 11 & 13 & 25 & 50 & & 6.24 \\
\hline \multirow{2}{*}{$\begin{array}{l}\text { Q7: Being positive? (having a positive approach and } \\
\text { a positive attitude; being honest but not negative } \\
\text { about your problems) }\end{array}$} & Pre-PCl & 1 & 1 & - & 5 & 8 & 13 & 23 & 51 & \multirow{2}{*}{0.40} & 5.92 \\
\hline & Post-PCl & - & - & 1 & 1 & 11 & 11 & 26 & 50 & & 6.20 \\
\hline \multirow{2}{*}{$\begin{array}{l}\text { Q8: Explaining things clearly? (fully answering your } \\
\text { questions, explaining clearly, giving you adequate } \\
\text { information; not being vague) }\end{array}$} & Pre-PCl & - & 1 & 1 & 3 & 9 & 14 & 23 & 51 & \multirow{2}{*}{0.73} & 6.02 \\
\hline & Post-PCl & - & - & - & 2 & 7 & 20 & 21 & 50 & & 6.20 \\
\hline \multirow{2}{*}{$\begin{array}{l}\text { Q9: Helping you to take control? (exploring with you } \\
\text { what you can do to improve your health yourself; } \\
\text { encouraging rather than "lecturing" you) }\end{array}$} & Pre-PCI & 2 & - & - & 5 & 7 & 14 & 22 & 50 & \multirow{2}{*}{0.95} & 5.90 \\
\hline & Post-PCl & - & - & - & 6 & 5 & 19 & 20 & 50 & & 6.06 \\
\hline \multirow{2}{*}{$\begin{array}{l}\text { Q10: Making a plan of action with you? (discussing } \\
\text { the options, involving you in decisions as much as } \\
\text { you want to be involved; not ignoring your views) }\end{array}$} & Pre-PCl & - & 1 & 1 & 3 & 6 & 14 & 25 & 50 & \multirow{2}{*}{0.83} & 6.12 \\
\hline & Post-PCl & - & - & - & 4 & 7 & 13 & 26 & 50 & & 6.22 \\
\hline \multirow{2}{*}{$\begin{array}{l}\text { Q11: Overall, how would you rate your consultation } \\
\text { with this doctor today? }\end{array}$} & Pre-PCI & 1 & 1 & - & 2 & 6 & 13 & 28 & 51 & \multirow{2}{*}{0.38} & 6.18 \\
\hline & Post-PCl & - & - & - & 1 & 7 & 11 & 32 & 51 & & 6.45 \\
\hline
\end{tabular}


Table 4. $\mathrm{PCl}$ concerns and patient satisfaction before and after the introduction of the $\mathrm{PCl}$, stratifying for HAQ score.

\begin{tabular}{|c|c|c|c|c|c|}
\hline & & $\mathrm{HAQ}<0.50$ & HAQ 0.50-0.99 & HAQ $1.00+$ & HAQ NK \\
\hline \multicolumn{6}{|l|}{$\mathrm{PCl}$ concerns } \\
\hline \multirow{2}{*}{$\begin{array}{l}\text { Domain D1: } \\
\text { Physical and } \\
\text { functional well- } \\
\text { being }\end{array}$} & Pre-PCl & $2.35(20)$ & $3.40(10)$ & $3.10(10)$ & $2.00(14)$ \\
\hline & Post-PCl & $2.20(5)$ & $4.73(15)$ & $6.62(13)$ & $4.39(18)$ \\
\hline \multirow{2}{*}{$\begin{array}{c}\text { Domain D2: } \\
\text { Treatment related } \\
\text { concerns }\end{array}$} & Pre-PCl & $2.00(20)$ & $1.70(10)$ & $3.10(10)$ & $2.50(14)$ \\
\hline & Post-PCl & $0.80(5)$ & $2.53(15)$ & $2.77(13)$ & $2.78(18)$ \\
\hline \multirow{2}{*}{$\begin{array}{l}\text { Domain D3: Social } \\
\text { care and well-being }\end{array}$} & Pre-PCl & $0.45(20)$ & $0.10(10)$ & $0.30(10)$ & $0.21(14)$ \\
\hline & Post-PCl & $0.60(5)$ & $1.07(15)$ & $1.46(13)$ & $1.83(18)$ \\
\hline \multirow{2}{*}{$\begin{array}{c}\text { Domain D4: } \\
\text { Psychological, } \\
\text { emotional and } \\
\text { spiritual well-being }\end{array}$} & Pre-PCl & $1.05(20)$ & $1.20(10)$ & $1.10(10)$ & $0.86(14)$ \\
\hline & Post-PCl & $0.60(5)$ & $1.40(15)$ & $1.69(13)$ & $1.61(18)$ \\
\hline \multirow{2}{*}{ Total concerns } & Pre-PCI & $5.85(20)$ & $6.40(10)$ & $7.60(10)$ & $5.57(14)$ \\
\hline & Post-PCI & $4.20(5)$ & $9.73(15)$ & 12.54 (13) & $10.61(18)$ \\
\hline \multicolumn{6}{|c|}{ Patient satisfaction Questionnaire } \\
\hline \multirow{2}{*}{$\begin{array}{l}\text { Q1: Making you } \\
\text { feel at ease? }\end{array}$} & Pre-PCl & $6.61(18)$ & $6.00(8)$ & $5.10(10)$ & $6.14(14)$ \\
\hline & Post-PCl & $6.60(5)$ & $6.53(15)$ & $6.42(12)$ & $6.33(18)$ \\
\hline \multirow{2}{*}{$\begin{array}{l}\text { Q2: Letting you tell } \\
\text { "your" story? }\end{array}$} & Pre-PCl & $6.47(19)$ & $6.13(8)$ & $5.10(10)$ & $5.86(14)$ \\
\hline & Post-PCl & $6.20(5)$ & $6.20(15)$ & $6.25(12)$ & $6.00(18)$ \\
\hline \multirow{2}{*}{$\begin{array}{l}\text { Q3: Really } \\
\text { listening? }\end{array}$} & Pre-PCl & $6.47(19)$ & $5.88(8)$ & $5.10(10)$ & $5.79(14)$ \\
\hline & Post-PCl & $6.00(5)$ & $6.47(15)$ & $6.17(12)$ & $6.11(18)$ \\
\hline \multirow{2}{*}{$\begin{array}{c}\text { Q4: Being } \\
\text { interested in you as } \\
\text { a whole person? }\end{array}$} & Pre-PCl & $6.33(18)$ & $5.75(8)$ & $5.00(9)$ & $5.79(14)$ \\
\hline & Post-PCl & $6.20(5)$ & $6.40(15)$ & $6.17(12)$ & $6.22(18)$ \\
\hline \multirow{2}{*}{$\begin{array}{c}\text { Q5: Fully } \\
\text { understanding your } \\
\text { concerns? }\end{array}$} & Pre-PCl & $6.42(19)$ & $6.00(8)$ & $5.20(10)$ & $5.86(14)$ \\
\hline & Post-PCl & $6.00(5)$ & $6.47(15)$ & $6.17(12)$ & $5.94(18)$ \\
\hline \multirow{2}{*}{$\begin{array}{l}\text { Q6: Showing care } \\
\text { and compassion? }\end{array}$} & Pre-PCl & $6.47(19)$ & $5.75(8)$ & $5.00(10)$ & $6.00(14)$ \\
\hline & Post-PCl & $6.20(5)$ & $6.53(15)$ & $6.25(12)$ & $6.00(18)$ \\
\hline \multirow{2}{*}{ Q7: Being positive? } & Pre-PCl & $6.47(19)$ & $5.75(8)$ & $4.90(10)$ & $6.00(14)$ \\
\hline & Post-PCl & $6.20(5)$ & $6.60(15)$ & $6.17(12)$ & $5.89(18)$ \\
\hline \multirow{2}{*}{$\begin{array}{l}\text { Q8: Explaining } \\
\text { things clearly? }\end{array}$} & Pre-PCl & $6.47(19)$ & $5.75(8)$ & $5.20(10)$ & $6.14(14)$ \\
\hline & Post-PCl & $6.00(5)$ & $6.33(15)$ & $6.25(12)$ & $6.11(18)$ \\
\hline \multirow{2}{*}{$\begin{array}{l}\text { Q9: Helping you to } \\
\text { take control? }\end{array}$} & Pre-PCl & $6.37(19)$ & $5.75(8)$ & $4.90(10)$ & $6.08(14)$ \\
\hline & Post-PCl & $6.00(5)$ & $6.20(15)$ & $6.08(12)$ & $5.94(18)$ \\
\hline \multirow{2}{*}{$\begin{array}{l}\text { Q10: Making a plan } \\
\text { of action with you? }\end{array}$} & Pre-PCl & $6.53(19)$ & $6.00(8)$ & $5.30(10)$ & $6.23(14)$ \\
\hline & Post-PCl & $6.00(5)$ & $6.40(15)$ & $6.08(12)$ & $6.22(18)$ \\
\hline \multirow{2}{*}{$\begin{array}{l}\text { Q11: Overall, how } \\
\text { would you rate } \\
\text { your consultation } \\
\text { with this doctor } \\
\text { today? }\end{array}$} & Pre-PCl & $6.58(19)$ & $6.38(8)$ & $5.30(10)$ & $6.14(14)$ \\
\hline & Post-PCl & $6.60(5)$ & $6.53(15)$ & $6.23(12)$ & $6.50(18)$ \\
\hline \multirow{2}{*}{ Mean score } & Pre-PCI & 6.47 (19) & $5.92(8)$ & $5.11(10)$ & $5.99(14)$ \\
\hline & Post-PCI & $6.18(5)$ & 6.42 (15) & 6.20 (12) & $6.12(18)$ \\
\hline
\end{tabular}


Figure 1 Percentage of participants discussing each concern item in the post-PCI group.

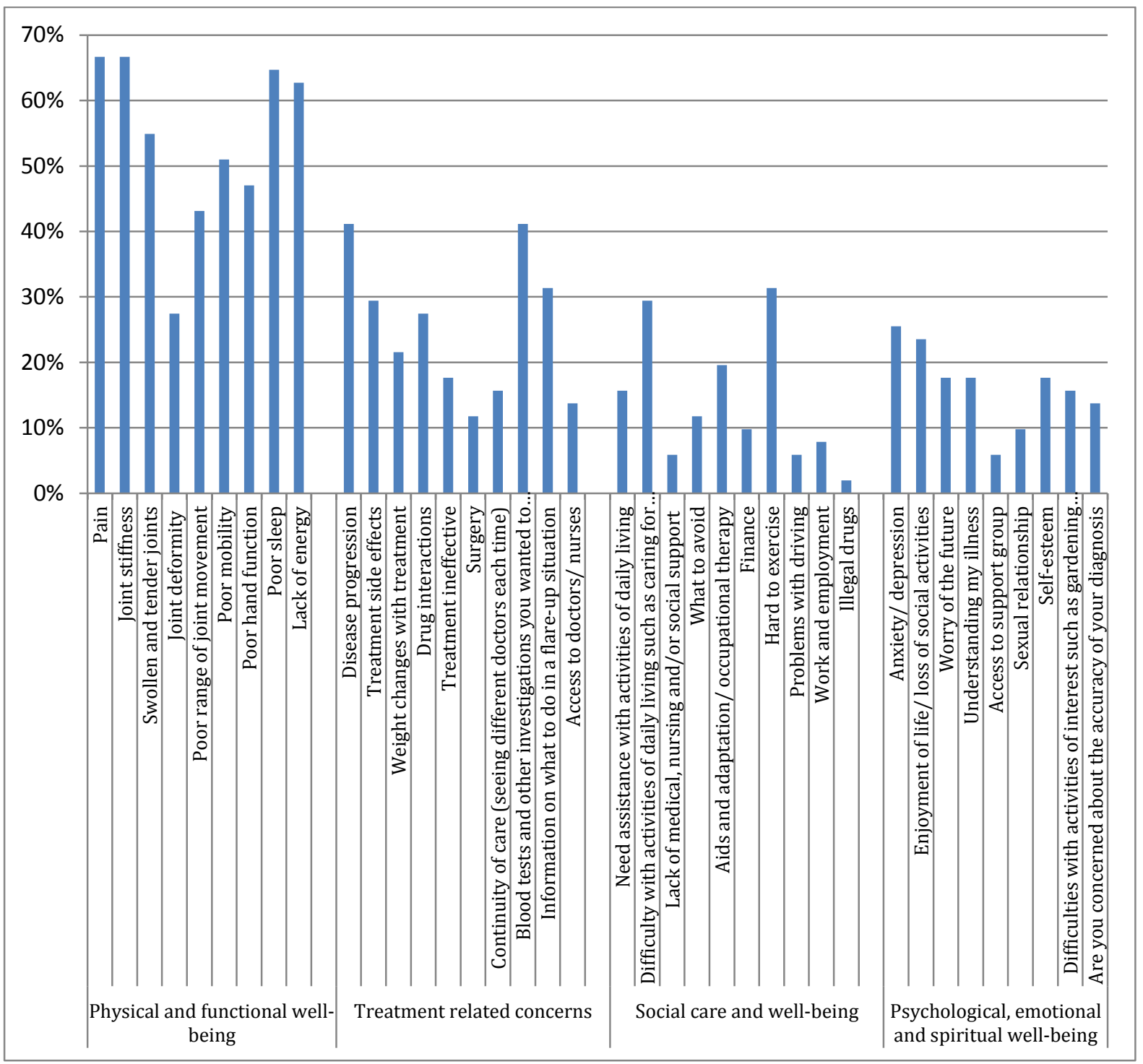

